\title{
Practices of Low Carbon Economy in China: Challenges and Opportunities for Economic Development
}

\author{
Md. Nazirul Islam Sarker ${ }^{1}$, Md. Altab Hossin², Jhensanam Anusara3, \\ Bouasone Chanthamith ${ }^{1}$, Nitin Kumar ${ }^{3}$ \\ ${ }^{1}$ School of Public Administration, Sichuan University, Chengdu, China \\ ${ }^{2}$ Department of Management Science and Engineering, University of Electronic Science and Technology of China, Chengdu, \\ China \\ ${ }^{3}$ Business School, Sichuan University, Chengdu, China \\ Email: sarker.scu@yahoo.com
}

How to cite this paper: Sarker, Md.N.I., Hossin, Md.A., Anusara, J., Chanthamith, B. and Kumar, N. (2018) Practices of Low Carbon Economy in China: Challenges and Opportunities for Economic Development. Low Carbon Economy, 9, 18-32. https://doi.org/10.4236/lce.2018.91002

Received: December 29, 2017

Accepted: March 10, 2018

Published: March 13, 2018

Copyright $\odot 2018$ by authors and Scientific Research Publishing Inc. This work is licensed under the Creative Commons Attribution International License (CC BY 4.0).

http://creativecommons.org/licenses/by/4.0/

\begin{abstract}
Global warming is a major concern in the globalized world in the aspect of industrialization. Low carbon practices are the major strategies to control global warming. Low carbon economy is the fundamental pattern of the mainstream economy in the perspective of ecology. The aim of this study is to explore the status of low carbon economy of China through assessing low carbon practices. It also finds out the challenges and opportunities of low carbon practices for sustainable economic development. An extensive literature review with meta-analysis has been done considering various indicators of low carbon practices. The study explores that China already adopted some policy, strategy, and practices regarding low carbon economy. China already set its policy regarding control of carbon emission by 2030. Research and innovation in low carbon practices, low carbon industrial structure, low carbon technology adoption and emphasizes on environmental sustainability are the major initiatives of China for low carbon economy. Major challenges regarding low carbon practices are heavy pressure on carbon emission, heavy industrialization, extensive development stream, resource endowment, unplanned industrial structure and trade, and confusion regarding industrial transformation. This study suggests that vigorous and efficient planning in industrialization, improved technology adoption, ecological consideration in every project and sufficient finance are necessary to obtain better low carbon economy in China.
\end{abstract}

\section{Keywords}

Global Warming, Climate Change, Low Carbon Economy, Sustainable 


\section{Introduction}

Carbon dioxide $\left(\mathrm{CO}_{2}\right)$ emission control is the top priority issue for civilization. Climate change is the result of excessive $\mathrm{CO}_{2}$ emission. Green House Gas (GHG) and $\mathrm{CO}_{2}$ emission are not only mattered for climate change but also effects on the social, political and economic matters. This issue is undoubtedly a great concern in the globalized world. United Nations Framework Convention on Climate Change (UNFCCC) arranged a conference for agreement among parties to control $\mathrm{CO}_{2}$ emission. Copenhagen accord agreed in 2009 for the continuation of Kyoto protocol. The global community agreed that climate change is the top issue for the present world due to its adverse effect on the livelihood of the people. There is no other way to control the climate change without low carbon practices. In 2011 Conference of the Parties (COP) in Durban are agreed to emit low carbon through low carbon practices within a short time. The developing countries which near to sea level are the major victims of the global warming and climate change. In Doha 2012, an amendment of Kyoto Protocol has been adopted for 8 years second commitment period to control greenhouse gases. According to last fifth IPCC report, $2^{\circ} \mathrm{C}$ global warming is the maximum limit to avoid the adverse effect on climate \& urgent to avoid significant risk. The energy sector is one of the most contributing sectors for GHG emission and clean energy production is the topmost priority challenge. All the parties of GHG emission agreed that the maximum limit of global warming is $2^{\circ} \mathrm{C}$ temperature and need to be zero GHG emission by 2020 [1]. A High level of technological, social \& political innovation is necessary for sustainable mitigation of the challenge regarding global warming [2]. Fossil fuels are the main source of GHG emission which covers more than $80 \%$ global energy consumption. So, low carbon economy achievement is a global challenge which can protect climate change effects. Therefore, a proper step should be taken by the developed countries as well as developing countries to achieve the goals. Actually, there is a complex relationship between environment and economic development [3]. Therefore, the natural energy source is the main source for the energy source is the main source of energy consumption for today and future without hampering the future generation [4]. Since the traditional economy is mainly based on fossil fuel, so alternative practices should find out to protect and preserve our future and develop low carbon economy for all [5]. The clean renewable energy source is the main strategy of low carbon economy [6]. The transformation from a traditional economy to low carbon economy is really challenging because it requires a proper plan, technological innovation and renewable sources of energy [7]. According to Biermann, Kanie, \& Kim [8] practicing LCE technology may be a cause of job losses in some sectors but it will create more jobs than losing. A low carbon economy can give a greater social equity in developing country through innovation of power generation technology and help rural poor communities for getting electricity, modern health care and clean water [9]. China is a top populated country with vast industrialization. Though it is still under traditional 
economic growth model with energy intensity and serious pollution [3]. But China is trying to adopt low carbon practices for its sustainable and low carbon economy. The purpose of this study is to explore the status of low carbon practices and challenges and opportunities facing at the implementation of LCE technology. This study contributes to discipline in items of theory and practices by exploring practices, challenges and opportunities of LCE for China as well as other developing and developed countries. It is beneficial for the practitioners, policymakers, and researcher to design future low carbon strategy plan and program for achieving low carbon economy.

In 2009 , the observed average decarbonization was $0.8 \%$ with high carbon intensity to more than $400 \mathrm{tCO} / \$ \mathrm{~m}$. Figure 1 also shows at projection rate $3.7 \%$ in 2039 with projected decarbonization at $0.8 \%$.

\section{Methodology}

\subsection{Research Design}

A conceptual model is developed for sustainable low carbon economic development in China through an extensive review of the literature [10]. The research is descriptive in nature based on some indicators of low carbon economy practices. The study mainly focuses on implementation challenges and opportunities of practices of low carbon economy in China.

\subsection{Sources of Data}

Secondary sources have been extensively used related to low carbon technology, low carbon practices, challenges and opportunities in the process of adoption of modern eco-friendly technologies, low carbon governance, climate change effects, air and water pollution and the adverse effect of the unplanned future

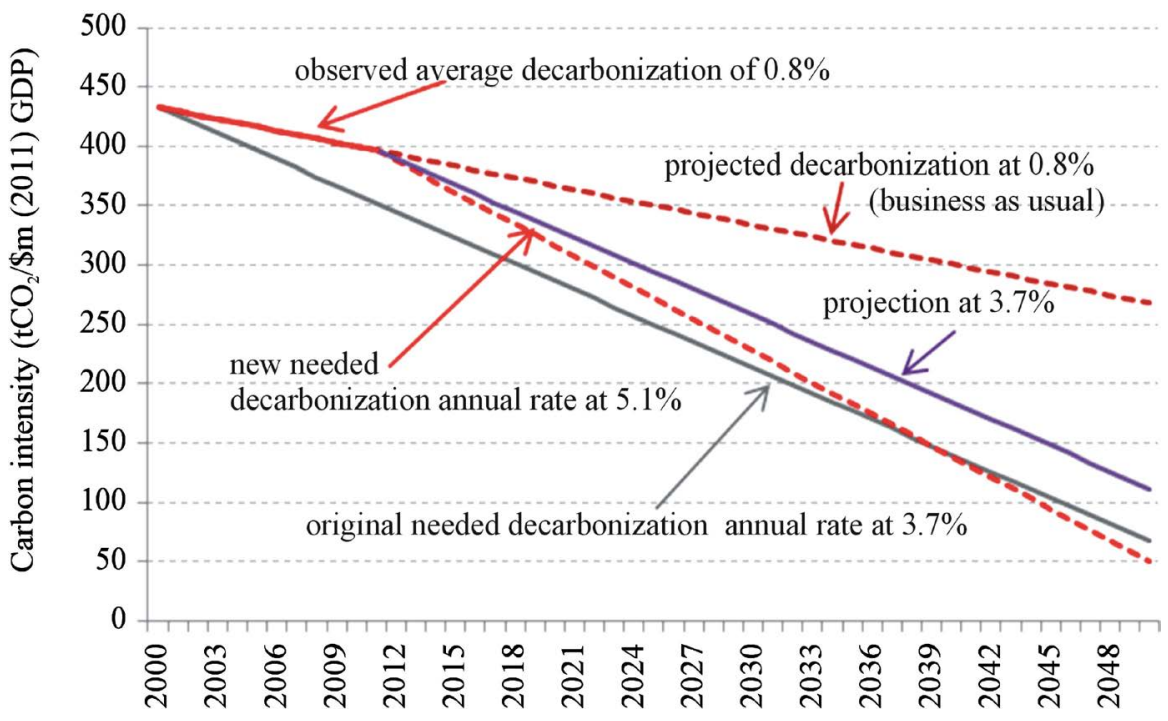

Figure 1. Linear rate of the global carbon intensity (decarbonization) expected for 2050, based on the PwC's Low Carbon Economy Index-Global. Source: Adapted from Bala [7]. 
economy. The latest information has been included for a better recommendation for low carbon economy. China has been focused on this study but it is applicable for other developed countries.

\subsection{Search Strategy}

Some renowned databases has been extensively searched like Google scholar, a web of science, science direct, Springer link, banglajol website using important keywords like low carbon, technology, economy, challenges, climate change, market, adverse effect, and China for securing authentic information [11]. The data collection and analysis for this study has been done from October to November 2017. Literature reviews are a significant part of the development of a field [12]. They offer the opportunity to synthesize and reflect on previous research, and thus providing secure grounding for the advancement of knowledge [13]. This kind of methodology used by Beamish for systematic illustration of phenomena (Figure 2).

\subsection{Data Analysis}

Data is analyzed from different perspectives of low carbon practices, technologies, indicators, challenges and opportunities of technology adoption, climate change effect and environmental governance.

\section{Review of Related Work}

Bo-Feng et al. [14] mentioned that China got the top position of carbon emission and low carbon society is necessary for protecting adverse effect of climate change globally. Low carbon governance is necessary for maintaining low carbon practices. Giurca \& Späth [5] analyzed internal and external system weaknesses and highlighted policies, actor networks market, and technological weakness. They

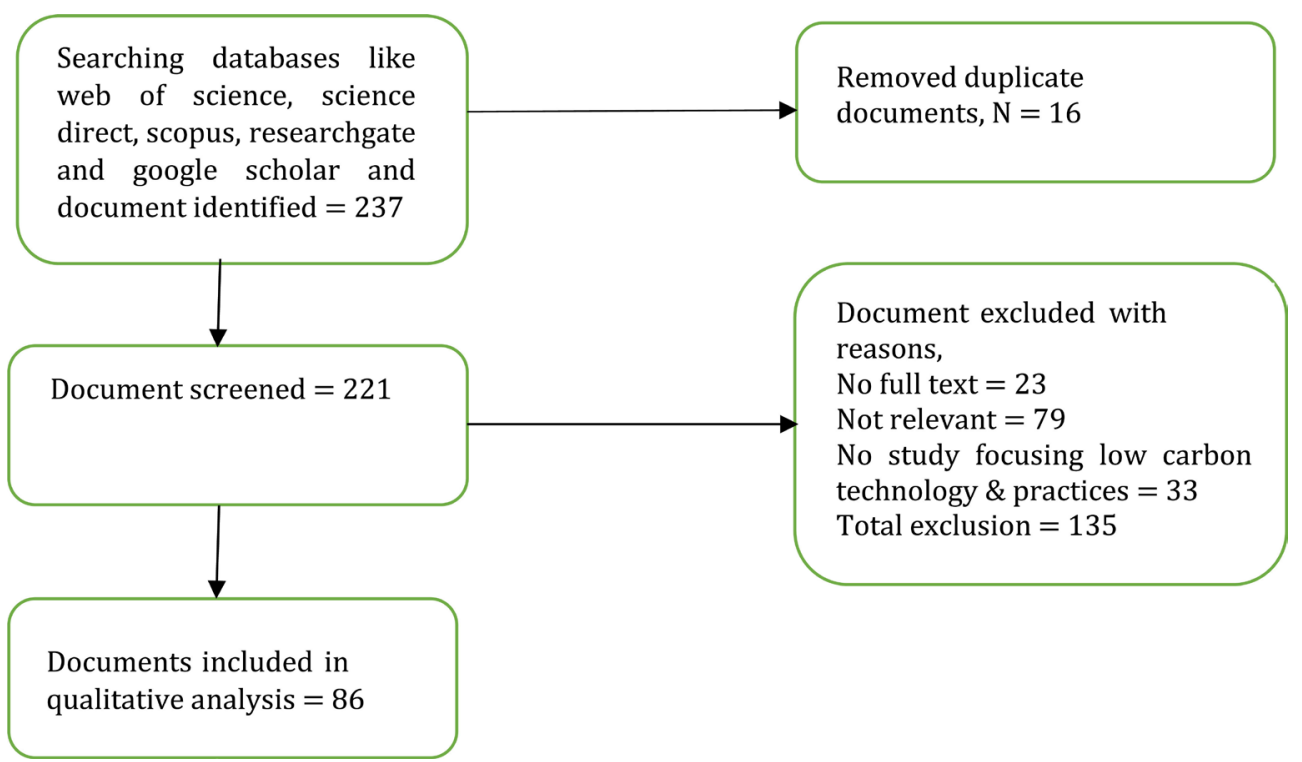

Figure 2. Flow diagram of study selection. 
argued that the innovation system presents a series of strengths as well. Some big cities are trying to reduce carbon emission and environmental protection [15]. China is the world's largest country in terms of the GHG emitter, energy producer and energy consumer for which China ranks first among other stakeholders. Fossil fuels and coal are the major sources of energy power [16]. In the perspective of climate change and sustainable economic development, low carbon economy is a new model of economic development [17]. China and South Korea are also facing these challenges and opportunities, so the governments have continually introduced policies to promote the realization of a low-carbon economy and hope to achieve a true eco-economy in the future [17]. China is rich in the total energy resources reserves, but possession of energy resources per capita is low, and some deficiencies are seriously restricting the sustainable economic and social development: 1) energy resources are difficult to exploit, 2) coal occupies a dominant role in primary energy supply, 3) environmental pollution is serious, and 4) the situation of energy supply and demand balance is severe [18]. China's primary energy production and total energy consumed reached 2.75 and 3.07 billion tons in 2009 standard coal equivalent respectively with the sustained and rapid growth of energy supply and demand [19] (Table 1).

\section{Current Status of Low Carbon Economy}

China is now at rapid industrialization stage high energy consumption is mandatory for high production in the industry [1]. It is very difficult for China to change its energy consumption pattern up to 2030. The $\mathrm{CO}_{2}$ emission probably will be less than 8 tons per capita by 2030 [42]. So, per capita, energy saving of China is very low that global average. But if China adopts the low carbon technology and strategy in its economic pattern, it is possible to reduce $20 \%$ GHG emission by 2030 [38]. A strategic vision should be taken by the authority of China for reducing carbon emission by adopting industrial restructuring, changing lifestyle, more efficiency in transport, industrial endues, building and electricity efficiency, and improving energy sector by using clean renewable energy [15].

Urbanization is another challenge for low carbon practices in China. It is the transformation of social structure. People of China prefer urban area for a living [43]. According to the survey of China city metabolize statistics, the urban population consume and limit GHS about $46 \%$ of the total population [44]. In terms of elements, the carbon emission is $86 \%$ iron, $88 \%$ aluminum, $75 \%$ cement, $80 \%$ energy and $92 \%$ copper [45]. Low carbon policies and practices should be considered in the process if rapid urbanization of China. Renewable energy is an emerging industry which has market potential and sustainable industrial development impacts with low carbon practices [46] [47]. Some developed countries emphasize on low carbon practices in the industry, as a remit the export-oriented sectors of China are little suppressed. So, carbon technology and policy adoption are the demand of time for using market potential, job creation and industrial 
Table 1. Major research on low carbon economy.

\begin{tabular}{|c|c|c|}
\hline Researcher \& duration & Summary of finding & Journal \\
\hline $\begin{array}{l}\text { Adenle, Manning, \& } \\
\text { Arbiol, (2017) [20] }\end{array}$ & $\begin{array}{l}\text { Meeting global climate change mitigation goals requires the participation of developing countries in } \\
\text { abatement programs to encourage low-carbon development pathways. }\end{array}$ & World Development \\
\hline $\begin{array}{l}\text { Ciplet \& Roberts, (2017) } \\
{[3]}\end{array}$ & $\begin{array}{l}\text { International neoliberal environmentalism as characterized by four main processes viz. the } \\
\text { prominence of libertarian ideals of justice, marketization; governance and mini-lateralism. }\end{array}$ & $\begin{array}{l}\text { Global Environmental } \\
\text { Change }\end{array}$ \\
\hline Keys et al., (2017) [21] & Moisture recycling governance is a key practice for low carbon economy & $\begin{array}{l}\text { Global Environmental } \\
\text { Change }\end{array}$ \\
\hline $\begin{array}{l}\text { Halkos \& Tzeremes, (2013) } \\
\text { [22] }\end{array}$ & $\begin{array}{l}\text { Six governance measures identified for low carbon practices like accountability, stability in politics } \\
\text { and no violence, effective government, quality regulatory process, rule of law and corruption } \\
\text { control. }\end{array}$ & Energy Economics \\
\hline Chen et al., (2017) [23] & $\begin{array}{l}\text { China has a target to reduce } 65 \text { percent carbon intensity by } 2030 \text { through modern energy technology } \\
\text { development and inducing innovation. }\end{array}$ & $\begin{array}{l}\text { Resources, Conservation } \\
\text { and Recycling }\end{array}$ \\
\hline $\begin{array}{l}\text { Zhang, Li, \& Zhou, (2017) } \\
\text { [24] }\end{array}$ & $\begin{array}{l}\text { The energy consumption and carbon emissions of the urban building sector have been growing so } \\
\text { rapidly in recent decades that developing low-carbon buildings has become a common trend in the } \\
\text { world. }\end{array}$ & $\begin{array}{l}\text { Journal of Cleaner } \\
\text { Production }\end{array}$ \\
\hline Liu et al., (2017) [25] & $\begin{array}{l}\text { Experiences from a bottom-up mechanism. Target Responsibility System (TRS) is still the key } \\
\text { working mechanism and makes a contribution to the reduction of } \mathrm{CO}_{2} \text { per unit GDP. }\end{array}$ & $\begin{array}{l}\text { Journal of Cleaner } \\
\text { Production }\end{array}$ \\
\hline $\begin{array}{l}\text { Lo, (2015) [26] } \\
\text { and Lo (2014) [27] }\end{array}$ & $\begin{array}{l}\text { Low-carbon policies cannot be properly implemented due to the poorly designed scoring system, } \\
\text { weak targets, energy intensity, and the lack of reliable local energy statistics. }\end{array}$ & $\begin{array}{l}\text { Environmental Science \& } \\
\text { Policy }\end{array}$ \\
\hline Han et al., (2018) [28] & $\begin{array}{l}\text { The local and neighboring cities in China emit more carbon due to specialization and diversification } \\
\text { industry. }\end{array}$ & $\begin{array}{l}\text { Journal of Cleaner } \\
\text { Production }\end{array}$ \\
\hline Yang et al (2018) [29] & The intensive energy consumption in urban sectors is aggravating global warming & $\begin{array}{l}\text { Journal of Cleaner } \\
\text { Production }\end{array}$ \\
\hline Fu \& Zhang, (2017) [30] & $\begin{array}{l}\text { The eco new towns are more concerned with the promotion of a sustainable way of life, with its } \\
\text { planning focus evenly distributed among all aspects. }\end{array}$ & Habitat International \\
\hline $\begin{array}{l}\text { Wang, Engels, \&Wang, } \\
\text { (2017) [32] }\end{array}$ & $\begin{array}{l}\text { Strong structural changes in existing development pattern are essential for low carbon development } \\
\text { in short and long-term. }\end{array}$ & $\begin{array}{l}\text { Renewable \& Sustainable } \\
\text { Energy Reviews }\end{array}$ \\
\hline Guo et al., (2017) [33] & $\begin{array}{l}\text { Carbon neutral coefficient }(\mathrm{CNC}) \text { can describe the positive impacts and limitations of ecological } \\
\text { environment policies. Subsequently, the approach of carbon balance analysis can help for } \\
\text { monitoring policy effectiveness for sustainable carbon economy. }\end{array}$ & $\begin{array}{l}\text { Resources, Conservation } \\
\text { and Recycling }\end{array}$ \\
\hline $\begin{array}{l}\text { X. Ma, Wang, \& Wang, } \\
\text { (2017) [34] }\end{array}$ & $\begin{array}{l}\text { If China's carbon emissions from the thermal power industry increase according to the present rate, } \\
\text { China will have difficulty in realizing its carbon reduction target by } 2020 \text {. }\end{array}$ & $\begin{array}{l}\text { Renewable and } \\
\text { Sustainable Energy } \\
\text { Reviews }\end{array}$ \\
\hline $\begin{array}{l}\text { Cheshmehzangi, Xie, \& } \\
\text { Tan-mullins, (2017) [35] }\end{array}$ & $\begin{array}{l}\text { The engagement between Chinese and international partners differ in three forms and they are 1) } \\
\text { the type of involvement; 2) the level and timeframe of involvement; 3) the level of Influence in the } \\
\text { project's multiple stages. }\end{array}$ & Cities \\
\hline Li et al., (2017) [36] & $\begin{array}{l}\text { Three main challenges are focused on low carbon economy viz. institutional inclusiveness, global } \\
\text { relations, and long-term innovation. }\end{array}$ & $\begin{array}{l}\text { Science of the Total } \\
\text { Environment }\end{array}$ \\
\hline B. Yang, (2017) [13] & $\begin{array}{l}\text { Carbon finance should be developed through modern tools, institutional arrangements, and strong } \\
\text { market actors. }\end{array}$ & Low Carbon Economy \\
\hline Krüger, (2017) [37] & $\begin{array}{l}\text { Efficiency enhancement and development of technological innovations are necessary for low carbon } \\
\text { economy. }\end{array}$ & Energy Policy \\
\hline Kedia, (2016) [38] & $\begin{array}{l}\text { China has already moved on low carbon development with fairly strongest domestic policies and } \\
\text { international engagement }\end{array}$ & $\begin{array}{l}\text { Advances in Climate } \\
\text { Change Research }\end{array}$ \\
\hline $\mathrm{He},(2016)[39]$ & $\begin{array}{l}\text { China has already explored green and low-carbon development strategy and established intended } \\
\text { nationally determined contribution (INDC) targets and action plans, consumption, efficient energy } \\
\text { production and transformation of traditional economic development pattern. }\end{array}$ & $\begin{array}{l}\text { Advances in Climate } \\
\text { Change Research }\end{array}$ \\
\hline Lv \& Qin, (2016) [40] & $\begin{array}{l}\text { Low-carbon technology mainly includes carbon reduction technology, carbon-free technology, } \\
\text { carbon removal technology, carbon management technology, resource saving and recycling } \\
\text { technology. }\end{array}$ & Low Carbon Economy \\
\hline Yuan, (2016) [41] & $\begin{array}{l}\text { Carbon finance not only provides a variety of means of support to the development of low carbon } \\
\text { economy but also offers a new development space for the innovation of the financial system. }\end{array}$ & Low Carbon Economy \\
\hline
\end{tabular}


development in China [40]. Environmental pollution is another concern in China. The traditional and old industry of China is based on high carbon emission technology and it is the major cause of environmental pollution [12]. High carbon emission has as adverse consequences an environmentally friendly and energy saving technology adoption ecological civilization in China. Chinese export business is mainly based on high energy and resources consumption and about $1 / 4$ of the global consumption and $1 / 5$ of the global carbon emission [9]. This amount will be increased in future with increasing population and industrialization and urbanization. Therefore, China is facing so much internal as well as external pressure as reducing GHG emission [48].

China has already taken some policies and actions regarding low carbon practices for protecting climate change effects. It is announced that China will reduce $40 \%$ to $50 \% \mathrm{CO}_{2}$ emission per limit GDP by 2020 and $60 \%$ to $65 \%$ by 2030 [12]. China also planned to develop renewable clean energy $20 \%$ by 2020 . It is a plan to transform China's traditional economic pattern to low carbon economy. China already initiated National Development and Reform Commission (NDRC). At first stage, 42 cities or province were selected for pilot projects during 2010 to 2012. The number of pilot projects as increased up to 87 at its third phase [25]. NDRC also declared other 55 cities for pilot projects for further demonstration at a various administrative level in 2014. The idea and initiative have been accepted by the people of China for reducing adverse effects of GHG emission. The pilot project of GHG emission. The pilot project included same key policy areas like renewable energy, more participation, exchange of experience among different stakeholders and adoption of low carbon technology [33]. It also ensures the horizontal as well as vertical communications between government agencies and other external stakeholders [27] [29]. The Ministry of Industry and Information Technology initiated a policy regarding low carbon park for promoting low carbon practices in 2014 [25].

\section{Opportunities for China's Low Carbon Economy Development}

As a rapidly developing country, China has a number of potential for low carbon economy development. China needs to adopt energy saving, carbon emission reduction technology, and clean renewable energy technology through strengthening research and innovation in some key areas with potential and competitive advantages [49]. There are a number of scopes to develop low carbon technology in China like carbon intensity reduction, reducing carbon emission, increasing use of renewable energy and reducing energy consumption [28]. The industrial and consumption structure in China is based on high energy consumption and low energy saving technologies due to low energy intensity and energy efficiency [31]. Therefore, it creates vulnerability in the management of energy. China can easily take opportunities for energy saving and low carbon emission through technological innovation, management and restructuring of 
the technologies in individual sectors [33]. The expense of low carbon technology in China is much lower than other developed countries. So, China can take easily this advantage to renovate the old industry through adoption of low carbon technology and set up the new industry with adopting low carbon technology [15]. In case of innovation and cooperation of carbon emission technologies, China has a big potential. Actually, there is a large gap between China and other developing countries in terms of low carbon technology adoption [50]. China needs to increase international cooperation and share technical experiences with international partners for gaining low carbon technology and establish a low carbon economy [51].

\section{Challenges of Low Carbon Economy}

\subsection{Rapid Urbanization}

China is now a stage of heavy industrialization and urbanization. Both Industrialization and urbanization are the major factors of high GHG emission. Due to urbanization, more people migrate to the city, urban areas, therefore, they require more energy, increasing consumption structure, more infrastructure construction and increasing GHG emission [49]. So, urbanization should be in a planned way for carbon economic development.

\subsection{Infrastructure}

The industrial infrastructure of China is characterized by heavy chemical industries, iron and steel industries, shipbuilding and vehicle industries and mechanical engineering industries [1]. These infrastructures require a large amount of energy as well as heavy materials. Some Chinese scholar thinks that main pillar of the economy of China is based on energy-intensive industries [52] [53]. Energy consumption rate is varying from province to province to province in China intense of industrialization and economic development [6]. The old industry structure is based on heavy energy consumption due to over-reliance or carbon-intensive source as well as the natural endowment of energy in China [54].

\subsection{Extensive Development Pattern}

The energy consumption per unit GDO of China is higher than global average due to high input, high consumption and high energy dependent technologies [13]. The extensive development pattern is established based on high energy consumption. The development pattern should be transformed to low carbon consumption without hampering production level by adopting low carbon technologies [50] (Figure 3).

\subsection{Building Sector}

About $28 \%$ of the total energy of China consumed by building sector [14]. China has a plan to increase 20 billion $\mathrm{m}^{2}$ housing area by 2020 through extensive 


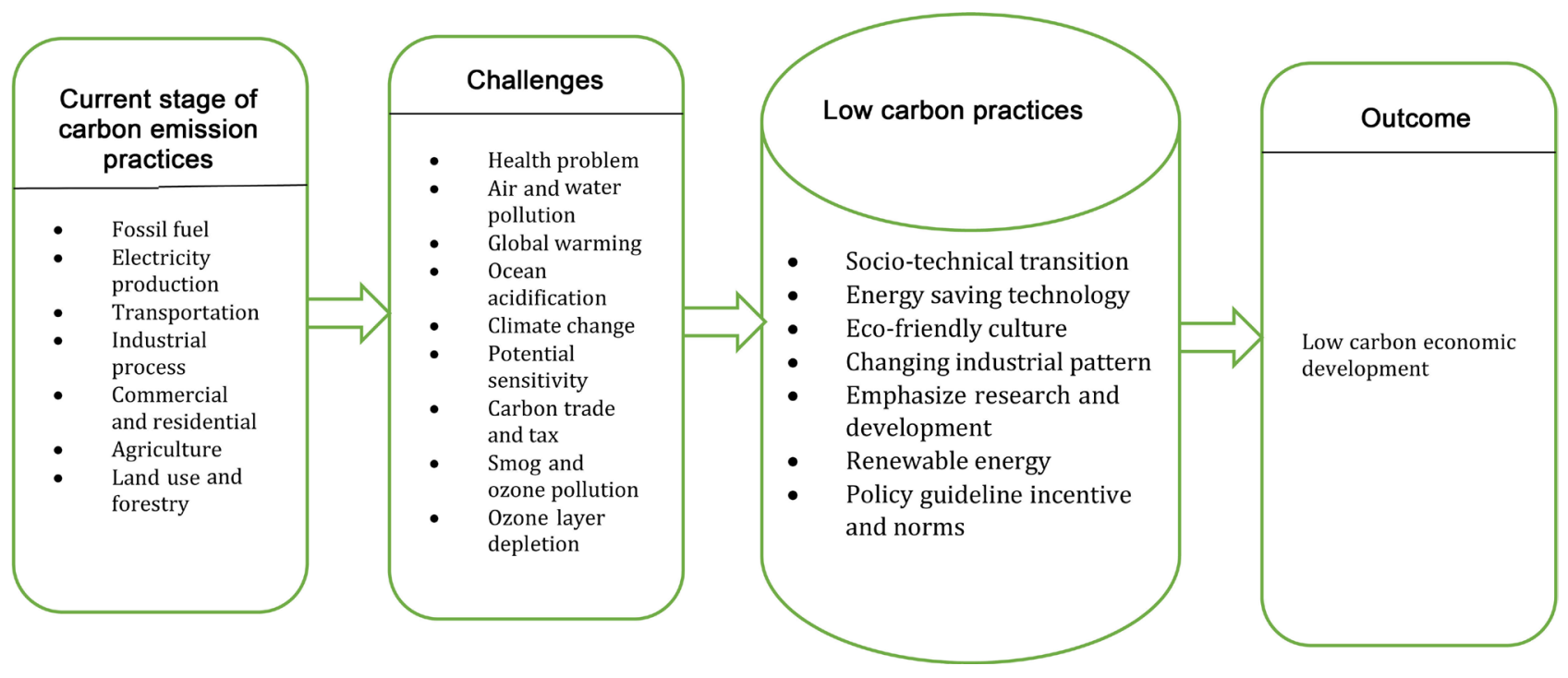

Figure 3. A conceptual model for developing low carbon economy in China.

development of housing sector [45]. For doing so, it requires so much energy and emits GHG. It is a big challenge to reduce GHG emission in the building sector. Some cities in China already adopted Time of Use (TOU) power policies to save energy [55]. China is energy auditing policy is not being implemented effectively energy auditing can change the energy consumption and save energy. A proper step should be taken by the authority to promote coherence among energy policy, tax and fiscal policy for developing low carbon economy [56].

\subsection{Energy Endowment and Structure}

The main slogan of energy structure is "rich coal, poor oil and less gas" [57]. It determines that the energy production in China is based on coal. The energy volume of per capita is 135 tons of standard coal which equivalent to $51 \%$ of global per capita of which coal, oil, and gas are $70 \%, 11 \%$ and $4 \%$ of global average volume respectively [58]. This practice is opposite to low carbon practices. So, China needs to adopt the clean renewable energy for sustainable low carbon economy [8] [59].

\subsection{Transport Sector}

One of the recognized GHG emission sectors is transport sector. The transport sector is one of largest sector in Chinese economy [60]. Since it contributes a lot GHG emission so low carbon technology should have adopted by this sector [49]. The government needs to take proper steps for introducing low carbon technology to transport sector. Technological, as well as behavioral positive change, is necessary for the development of low carbon transport sector [53].

\subsection{Industrial and Trade Sector}

Industrial and trade structure of China is very far from other developed countries like the US, Japan and EU in terms of competitiveness, technical content 
and value-added products [61]. The development countries already adopted knowledge of industry and trade. China can reduce this gap by adopting low carbon technology which is based on knowledge economy [62].

\subsection{Confusion in Industrial Transformation}

Industrial transformation is a big challenge for China as largest economy since economy since the economy of China is based on industrialization [13]. So, there is a confusion between the transformation of industry and livelihood improvement of the people of China. China already faces some challenges regarding livelihood of people who already engaged with industrialization in terms of job opportunities [44]. Income disparities, poverty and counter-poverty and living standard. Energy consumption is necessary and inevitable for serving people who are living at the countryside of China for better life leading.

\section{Pathway for Economic Development}

1) Low carbon economy is necessary to build an ecologically civilized society in terms of energy saving, eco-friendly cultures, sustainable and low carbon orientation [63]. Low carbon practices should be adopted by the government authorities for planning, policy development and implementation in new industrialization and new city construction cases.

2) Technological progress and structural adjustments are necessary in China for low carbon economy [40]. The adoption of improvement technology and structural transformation can be done by two or three stages considering carbon emission, the process of industrialization and urbanization [1]. China has already taken initiative for low carbon economic development by launching pilot projects [64]. It is the greatest initiative to develop low carbon economy.

3) China should need to emphasize to R\&D for developing modern low carbon technology by supporting the rapid diffusion and using present low carbon technologies, financing and nationalizing venture investment focusing on medium and long-term strategies [65]. China should promote low carbon technology research and gain research experiences from other development countries. As a big consumer China consumed economic outputs only less than $10 \%$ of developed countries. According China is the largest manufacturer and trader in the world [66]. So low carbon technologies should be adopted by all potential sectors for low carbon economic development [45].

4) Energy saving and low carbon development of China can be done by consider are main method like market means and two supplementing methods like government means and moral means [47]. According to Wenling Liu et al. [44] Energy saving can be adopted in effect ways through three ways viz. government, morality and market. Government should take initiative to develop market environment for low carbon emission and market mechanism [67].

5) Many technologies related to for energy production are available but not properly used by concern sectors. Government need to take initiative for proper 
deployment of the approximate technology to the right sectors for low carbon economy [68]. Not only should that government focus on alternative renewable and energy-saving technologies. Innovation of low carbon technologies should be a prior issue in energy policy for reducing dependency on fossil fuel [40]. A clean coal developed for saving energy in different sectors. A short-term incentive and long-term confidence policy framework should be developed to adopt low carbon technologies due to high prices than fossil fuel based energy [13].

6) Policy guideline, incentives and norms for low carbon development should be considered for innovation of new technology. Exports of same high-tech products of China are increasing in the global market but its inputs are largely depending on importing from other countries [55]. So, low carbon practices should be considered during export and imports of any product.

\section{Conclusion}

China is the largest country in terms of population, consumers, manufacturing, and trading. It is now in a stage of rapid urbanization and heavy industrialization. Carbon emission is intimately related to industrialization and urbanization. The article reveals that China already adopted policies, strategies and practices related to low carbon economic development. China declared energy policy to control carbon emission by 2030. The study further finds out same major initiatives for low carbon economy viz research and innovation in low carbon practices, low carbon industrial structure, low carbon technology adoption and emphasizes on a sustainable environment. This study finds out some challenges of low carbon practices like a heavy pressure on carbon emission, heavy industrialization, intensive development stream, resource endowment, unplanned industrial structure, and trade. The article suggests that efficient planning for industrialization, adoption of modern technology, ecological consideration in policy formulation and low carbon finance are the important measures to develop sustainable low carbon economy in China.

\section{References}

[1] Yu, L. (2014) Low Carbon Eco-City: New approach for Chinese Urbanization. Habitat International, 44, 102-110. https://doi.org/10.1016/j.habitatint.2014.05.004

[2] Aye, L., Bamford, N., Charters, B. and Robinson, J. (1999) Environmentally Sustainable Development: A Life Cycle Costing Approach for a Commercial Office Building in Melbourne, Australia. 15th Annual ARCOM Conference, 15-17 September 1999, Liverpool, 735-742.

[3] Ciplet, D. and Roberts, J.T. (2017) Climate Change and the Transition to Neoliberal Environmental Governance. Global Environmental Change, 46, 148-156. https://doi.org/10.1016/j.gloenvcha.2017.09.003

[4] Du, C. and Liu, Y. (2011) Constructing Energy Saving System Based on Low-Carbon Economy. Energy Procedia, 5, 1998-2002. https://doi.org/10.1016/j.egypro.2011.03.344

[5] Giurca, A. and Späth, P. (2017) A Forest-Based Bio-Economy for Germany? Strengths, Weaknesses and Policy Options for Lignocellulosic Biorefineries. Journal 
of Cleaner Production, 153, 51-62. https://doi.org/10.1016/j.jclepro.2017.03.156

[6] Holley, C. and Lecavalier, E. (2017) Energy Governance, Energy Security and Environmental Sustainability: A Case Study from Hong Kong. Energy Policy, 108, 379-389. https://doi.org/10.1016/j.enpol.2017.06.010

[7] Bala, G. (2013) Digesting 400 ppm for Global Mean $\mathrm{CO}_{2}$ Concentration. Current Science, 104, 10-11.

[8] Biermann, F., Kanie, N. and Kim, R.E. (2017) Global Governance by Goal-Setting: The Novel Approach of the UN Sustainable Development Goals. Current Opinion in Environmental Sustainability, 26-27, 26-31. https://doi.org/10.1016/j.cosust.2017.01.010

[9] Carrasco, J.F. (2014) The Challenge of Changing to a Low-Carbon Economy: A Brief Overview. Low Carbon Economy, 5, 1-5. https://doi.org/10.4236/lce.2014.51001

[10] Sarker, M.N.I. (2017). An Introduction to Agricultural Anthropology: Pathway to Sustainable Agriculture. Journal of Sociology and Anthropology, 1, 47-52.

[11] Sarker, M.N.I. and Jie, Z. (2017) Social Security for Vulnerable Groups in Bangladesh on Government Perspective: Contribution of Research Leader. Journal of Public Policy and Administration, 1, 1-9.

[12] Liu, C., Kuang, Y., Huang, N. and Liu, X. (2014) An Empirical Research on Evaluation of Low-Carbon Economy in Guangdong Province, China: Based on "Production, Life and Environment." Low Carbon Economy, 5, 139-152. https://doi.org/10.4236/lce.2014.54015

[13] Yang, B. (2017) China's Low-Carbon Economy Development and Carbon Finance Market Supervision Mechanism. Low Carbon Economy, 8, 97-105. https://doi.org/10.4236/lce.2017.84008

[14] Bo-Feng, C., Jin-Nan, W., Wei-Shan, Y., Lan-Cui, L. and Dong, C. (2012) Low Carbon Society in China: Research and Practice. Advances in Climate Change Research, 3, 106-120. https://doi.org/10.3724/SP.J.1248.2012.000106

[15] Tan, S., Yang, J., Yan, J., Lee, C., Hashim, H. and Chen, B. (2017) A Holistic Low Carbon City Indicator Framework for Sustainable Development. Applied Energy, 185, 1919-1930. https://doi.org/10.1016/j.apenergy.2016.03.041

[16] Monkelbaan, J. (2014) Addressing the Trade-Climate Change-Energy Nexus: China's Explorations in a Global Governance Landscape. Advances in Climate Change Research, 5, 206-218. https://doi.org/10.1016/j.accre.2015.04.001

[17] Li, D. and Kang, T. (2012) Inspiration from Green Effect of South Korea's Low-Carbon Economy Development to China. Low Carbon Economy, 3, 154-159. https://doi.org/10.4236/lce.2012.34020

[18] Ma, H., Oxley, L. and Gibson, J. (2009) China's Energy Situation in the New Millennium. Renewable and Sustainable Energy Reviews, 13, 1781-1799. https://doi.org/10.1016/j.rser.2009.01.018

[19] Hou, J., Zhang, P., Tian, Y., Yuan, X. and Yang, Y. (2011) Developing Low-Carbon Economy: Actions, Challenges and Solutions for Energy Savings in China. Renewable Energy, 36, 3037-3042. https://doi.org/10.1016/j.renene.2011.03.033

[20] Adenle, A.A., Manning, D.T. and Arbiol, J. (2017) Mitigating Climate Change in Africa: Barriers to Financing Low-Carbon Development. World Development, 100, 123-132. https://doi.org/10.1016/j.worlddev.2017.07.033

[21] Keys, P.W., Wang-Erlandsson, L., Gordon, L.J., Galaz, V. and Ebbesson, J. (2017) Approaching Moisture Recycling Governance. Global Environmental Change, 45, 
15-23. https://doi.org/10.1016/j.gloenvcha.2017.04.007

[22] Halkos, G.E. and Tzeremes, N.G. (2013) Carbon Dioxide Emissions and Governance: A Nonparametric Analysis for the G-20. Energy Economics, 40, 110-118. https://doi.org/10.1016/j.eneco.2013.06.010

[23] Chen, Q., Cai, B., Dhakal, S., Pei, S., Liu, C., Shi, X. and Hu, F. (2017) CO 2 Emission Data for Chinese Cities. Resources, Conservation and Recycling, 126, 198-208. https://doi.org/10.1016/j.resconrec.2017.07.011

[24] Zhang, L., Li, Q. and Zhou, J. (2017) Critical Factors of Low-Carbon Building Development in China's Urban Area. Journal of Cleaner Production, 142, 3075-3082. https://doi.org/10.1016/j.jclepro.2016.10.160

[25] Liu, T., Wang, Y., Song, Q. and Qi, Y. (2017) Low-Carbon Governance in China-Case Study of Low Carbon Industry Park Pilot. Journal of Cleaner Production, 174, 837-846. https://doi.org/10.1016/j.jclepro.2017.10.339

[26] Lo, K. (2015) How Authoritarian Is the Environmental Governance of China? Environmental Science \& Policy, 54, 152-159. https://doi.org/10.1016/j.envsci.2015.06.001

[27] Lo, K. (2014) China's Low-Carbon City Initiatives: The Implementation Gap and the Limits of the Target Responsibility System. Habitat International, 42, 236-244. https://doi.org/10.1016/j.habitatint.2014.01.007

[28] Han, F., Xie, R., lu, Y., Fang, J. and Liu, Y. (2018) The Effects of Urban Agglomeration Economies on Carbon Emissions: Evidence from Chinese Cities. Journal of Cleaner Production, 172, 1096-1110. https://doi.org/10.1016/j.jclepro.2017.09.273

[29] Yang, D., Liu, B., Ma, W., Guo, Q., Li, F. and Yang, D. (2017) Sectoral Energy-Carbon Nexus and Low-Carbon Policy Alternatives: A Case Study of Ningbo, China. Journal of Cleaner Production, 156, 480-490.

https://doi.org/10.1016/j.jclepro.2017.04.068

[30] Fu, Y. and Zhang, X. (2017) Planning for Sustainable Cities? A Comparative Content Analysis of the Master Plans of Eco, Low-Carbon and Conventional New Towns in China. Habitat International, 63, 55-66. https://doi.org/10.1016/j.habitatint.2017.03.008

[31] Wang, C., Engels, A. and Wang, Z. (2017) Overview of Research on China's Transition to Low-Carbon Development: The Role of Cities, Technologies, Industries and the Energy System. Renewable and Sustainable Energy Reviews, 81, 1350-1364.

[32] Wang, X. and Chi, C. (2016) Global City Indicators: Towards a Holistic View of Low Carbon City Dimensions. Energy Procedia, 88, 168-175. https://doi.org/10.1016/j.egypro.2016.06.042

[33] Guo, R., Zhao, Y., Shi, Y., Li, F., Hu, J. and Yang, H. (2017) Low Carbon Development and Local Sustainability from a Carbon Balance Perspective. Resources, Conservation and Recycling, 122, 270-279. https://doi.org/10.1016/j.resconrec.2017.02.019

[34] Ma, X., Wang, Y. and Wang, C. (2017) Low-Carbon Development of China's Thermal Power Industry Based on an International Comparison: Review, Analysis and Forecast. Renewable and Sustainable Energy Reviews, 80, 942-970. https://doi.org/10.1016/j.rser.2017.05.102

[35] Cheshmehzangi, A., Xie, L. and Tan-mullins, M. (2017) The Role of International Actors in Low-Carbon Transitions of Shenzhen's International Low Carbon City in China. Cities, 74, 64-74.

[36] Li, Z., Galeano Galván, M.J., Ravesteijn, W. and Qi, Z. (2017) Towards Low Carbon 
Based Economic Development: Shanghai as a C40 City. Science of the Total Environment, 576, 538-548. https://doi.org/10.1016/j.scitotenv.2016.10.034

[37] Krüger, T. (2016) Conflicts and Storage in International Climate Governance. Energy Policy, 100, 58-67.

[38] Kedia, S. (2016) Approaches to Low Carbon Development in China and India. Advances in Climate Change Research, 7, 213-221. https://doi.org/10.1016/j.accre.2016.11.001

[39] He, J.K. (2016) Global Low-Carbon Transition and China's Response Strategies. Advances in Climate Change Research, 7, 204-212. https://doi.org/10.1016/j.accre.2016.06.007

[40] Lv, J. and Qin, S. (2016) On Low-Carbon Technology. Low Carbon Economy, 7, 107-115. https://doi.org/10.4236/lce.2016.73010

[41] Yuan, Y. (2016) The Development Status, Problems and Countermeasures of China's Carbon Financial Market. Low Carbon Economy, 7, 62-69. https://doi.org/10.4236/lce.2016.71007

[42] Gouldson, A., Colenbrander, S., Sudmant, A., Papargyropoulou, E., Kerr, N., McAnulla, F. and Hall, S. (2016) Cities and Climate Change Mitigation: Economic Opportunities and Governance Challenges in Asia. Cities, 54, 11-19. https://doi.org/10.1016/j.cities.2015.10.010

[43] Chen, G.Q., Guo, S., Shao, L., Li, J.S. and Chen, Z.M. (2013) Three-Scale Input-Output Modeling for Urban Economy: Carbon Emission by Beijing 2007. Communications in Nonlinear Science and Numerical Simulation, 18, 2493-2506. https://doi.org/10.1016/j.cnsns.2012.12.029

[44] Liu, W., Spaargaren, G., Mol, A.P.J., Heerink, N. and Wang, C. (2014) Low Carbon Rural Housing Provision in China: Participation and Decision Making. Journal of Rural Studies, 35, 80-90. https://doi.org/10.1016/j.jrurstud.2014.04.005

[45] Zhang, Z. (2010) China in the Transition to a Low-Carbon Economy. Energy Policy, 38, 6638-6653. https://doi.org/10.1016/j.enpol.2010.06.034

[46] Liu, C. and Feng, Y. (2011) Low-Carbon Economy: Theoretical Study and Development Path Choice in China. Energy Procedia, 5, 487-493. https://doi.org/10.1016/j.egypro.2011.03.085

[47] Zhao, X., Wu, L. and Li, A. (2017) Research on the Efficiency of Carbon Trading Market in China. Renewable and Sustainable Energy Reviews, 79, 1-8. https://doi.org/10.1016/j.rser.2017.05.034

[48] Zeng, S. (2011) Literature Review of Carbon Finance and Low Carbon Economy for Constructing Low Carbon Society in China. Low Carbon Economy, 2, 15-19. https://doi.org/10.4236/lce.2011.21003

[49] Chen, Y., Tuerk, A., Kaltenegger, I. and Fruhmann, C. (2016) Low-Carbon Urban Development in China: Current Initiatives, Future Plans and First Lessons. POCACITO Policy Brief, 1.

[50] Su, M.R., Chen, B., Xing, T., Chen, C. and Yang, Z.F. (2012) Development of Low-Carbon City in China: Where Will It Go? Procedia Environmental Sciences, 13, 1143-1148.

[51] Leimer, H.P. (2015) Low Carbon Economy in the Cities of China-Possibilities to Estimate the Potential of $\mathrm{CO}_{2}$-Emissions. Energy Procedia, 78, 2250-2255. https://doi.org/10.1016/j.egypro.2015.11.351

[52] Lai, F. and Ren, J. (2011) On the Necessity and Governance Model of the Construction of China's Low-Carbon Transportation System. Energy Procedia, 5, 1502-1507. 
https://doi.org/10.1016/j.egypro.2011.03.257

[53] Zhou, N., He, G., Williams, C. and Fridley, D. (2015) ELITE Cities: A Low-Carbon Eco-City Evaluation Tool for China. Ecological Indicators, 48, 448-456. https://doi.org/10.1016/j.ecolind.2014.09.018

[54] Dou, X. (2013) Low Carbon-Economy Development: China's Pattern and Policy Selection. Energy Policy, 63, 1013-1020. https://doi.org/10.1016/j.enpol.2013.08.089

[55] Wang, Z. (2017) The Study of Carbon Cost Management under the Carbon Trading Mechanism-Based on the Value Chain Theory. Low Carbon Economy, 8, 51-62. https://doi.org/10.4236/lce.2017.82005

[56] Yang, L. and Li, Y. (2013) Low-Carbon City in China. Sustainable Cities and Society, 9, 62-66. https://doi.org/10.1016/j.scs.2013.03.001

[57] Huang, W., Wang, M., Wang, J., Gao, K., Chen, S.L. and Editors, L. (2016) China Low-Carbon Healthy City, Technology Assessment and Practice. Springer-Verlag GmbH Berlin Heidelberg. https://doi.org/10.1007/978-3-662-49071-6

[58] Liu, W. and Qin, B. (2016) Low-Carbon City Initiatives in China: A Review from the Policy Paradigm Perspective. Cities, 51, 131-138. https://doi.org/10.1016/j.cities.2015.11.010

[59] Baeumler, A., Ijjasz-Vasquez, E. and Mehndiratta, S. (2012) Sustainable Low-Carbon City Development in China.

[60] Zhou, G., Singh, J., Wu, J., Sinha, R., Laurenti, R. and Frostell, B. (2015) Evaluating Low-Carbon City Initiatives from the DPSIR Framework Perspective. Habitat International, 50, 289-299. https://doi.org/10.1016/j.habitatint.2015.09.001

[61] Yang, A., Wang, R. and Wang, J. (2017) Green Public Diplomacy and Global Governance: The Evolution of the U.S.-China Climate Collaboration Network, 2008-2014. Public Relations Review, 43, 1048-1061.

[62] Xin, J. and Wu, Y. (2011) The Quantitative Evaluation Method of Low-Carbon Economy Auditing. Energy Procedia, 5, 1014-1018. https://doi.org/10.1016/j.egypro.2011.03.179

[63] Niu, Y. (2011) The Economic Thinking on Low Carbon Economy. Energy Procedia, 5, 2368-2372. https://doi.org/10.1016/j.egypro.2011.03.407

[64] Khanna, N., Fridley, D. and Hong, L. (2014) China's Pilot Low-Carbon City Initiative: A Comparative Assessment of National Goals and Local Plans. Sustainable Cities and Society, 12, 110-121. https://doi.org/10.1016/j.scs.2014.03.005

[65] Price, L., Zhou, N., Fridley, D., Ohshita, S., Lu, H., Zheng, N. and Fino-Chen, C. (2013) Development of a Low-Carbon Indicator System for China. Habitat International, 37, 4-21. https://doi.org/10.1016/j.habitatint.2011.12.009

[66] Wang, N. and Chang, Y.C. (2014) The Development of Policy Instruments in Supporting Low-Carbon Governance in China. Renewable and Sustainable Energy Reviews, 35, 126-135. https://doi.org/10.1016/j.rser.2014.03.021

[67] Zhang, C., Wang, Q., Shi, D., Li, P. and Cai, W. (2016) Scenario-Based Potential Effects of Carbon Trading in China: An Integrated Approach. Applied Energy, 182, 177-190. https://doi.org/10.1016/j.apenergy.2016.08.133

[68] Zhang, J., Zeng, W., Wang, J., Yang, F. and Jiang, H. (2017) Regional Low-Carbon Economy Efficiency in China: Analysis Based on the Super-SBM Model with $\mathrm{CO}_{2}$ Emissions. Journal of Cleaner Production, 163, 202-211. https://doi.org/10.1016/j.apenergy.2016.08.133 